UDC 621.921.34-419:536

\author{
L. Jaworska, P. Klimczyk, M. Szutkowska, P. Putyra, \\ M. Sitarz, S. Cygan*, P. Rutkowski (Krakow, Poland) \\ *slawomir.cygan@ios.krakow.pl
}

\title{
Thermal resistance of PCD materials with borides bonding phase
}

In these studies, one group of PCD materials was prepared using diamond powder and 10 wt \% of $\mathrm{TiB}_{2}$ and the second batch of the PCD material was prepared using a mixture of diamond powder with 5 wt \% of $\mathrm{TiB}_{2}$ and 2 wt \% of Co. The materials have been sintered using a Bridgman-type high-pressure apparatus at 8.0 $\pm 0.2 \mathrm{GPa}$, at a temperature of $2000 \pm 50^{\circ} \mathrm{C}$. Thermogravimetric (TG) measurements and Differential Thermal Analysis (DTA) have been carried out for diamond micropowders, $\mathrm{TiB}_{2}$ bonding phase, and sintered composites. The coefficients of friction for diamond composites in a sliding contact with an $\mathrm{Al}_{2} \mathrm{O}_{3}$ ceramic ball have been determined from the room temperature up to $800^{\circ} \mathrm{C}$. Material phase compositions were analyzed for initial samples and after wear tests, at the temperature of $800^{\circ} \mathrm{C}$. Raman spectra of diamond composites with borides bonding phases, observed for the first-order zone centre modes of diamond and graphite during the heating up to $800{ }^{\circ} \mathrm{C}$ in air have been presented. Thermal properties have been compared with the commercial diamond-cobalt PCD. It has been found that diamond with $\mathrm{TiB}_{2}$ and $\mathrm{Co}$ is the most resistant to the hardness changes at elevated temperatures and this material maintains the high hardness value up to $800{ }^{\circ} \mathrm{C}$ but it has a high coefficient of friction. coefficient of friction.

Keywords: $\mathrm{PCD}, \mathrm{TiB}_{2}$ bonding phase, thermal stability, hardness,

\section{INTRODUCTION}

During machining of materials the majority of energy required to form the chips is converted into heat. A considerable amount of heat generated during machining is transferred into the cutting tool and workpiece [1]. The rate of heat transfer from the cutting zone is a very important parameter for machining. Increasing the heat in the cutting zone has a negative effect on the material of the tool tip. It may be negative, for example, for phase transformation processes (graphitization) or it may intensify the process of oxidation. Diamond is an allotropic form of carbon with a cubic structure, which is thermodynamically stable at the pressures above 1.6 GPa at room temperature and metastable at atmospheric pressure [2]. At low pressures natural diamond converts rapidly into graphite at $1600{ }^{\circ} \mathrm{C}$, in an inert atmosphere. During the diamond heat treatment two competitive processes occur, i.e. the oxidation accompanied by the surface graphitization [3]. The oxidation of synthetic diamond starts at a temperature lower than of natural diamond [4]. The oxidation of carbon (at $800{ }^{\circ} \mathrm{C}$ and higher) proceeds yielding gaseous $\mathrm{CO}$ and/or $\mathrm{CO}_{2}$ products. The graphitization and oxidation processes depend on size, purity of diamond particles and type of bonding phases for the polycrystalline diamond [5]. The growth temperature of diamond lies between the melting point of the solvent/catalyst/carbon system and 
the diamond-graphite equilibrium temperature [6]. The chemical composition and properties of synthetic diamond obtained by means of the high pressure-high temperature method depend on the type of a catalyst [7]. Cobalt belongs to the iron group of materials, which are known to be good solvents/catalysts for diamond synthesis and also for the binder phase during the diamond powder sintering [8]. The most popular polycrystalline diamonds (PCD) sintering technology is based on the infiltration of cobalt into diamond grain surfaces, the solution of carbon in cobalt, and reverse crystallization of carbon into diamond. Cobalt decreases graphitization temperature of the diamond. One of the possibilities to increase the thermal resistance of PCD materials is to reduce the cobalt bonding phase content. PCD with the cobalt bonding phase are chemically stable up to $700{ }^{\circ} \mathrm{C}$ because of the graphitization, while the working temperatures (without cooling) for this group of materials during the machining process in the cutting zone may rise even higher. In such a situation, the development of new bonding phases in diamond composites is very much needed. Thermal resistance of diamond composite depends on the oxidation more than on the graphitization. $\mathrm{CO}$ gas evolution during diamond composite oxidation destroys the integrity of the composite microstructure. An addition of a more oxidation resistant phase to diamond (PCD) can result in the possibility to use the diamonds cutting edge at higher temperatures and to obtain higher resistance to oxidation of the PCD. For the $\mathrm{TiB}_{2}$ surface oxidation occurs at temperatures below $1000{ }^{\circ} \mathrm{C}$, the weight gain is observed as a result of the formation of $\mathrm{TiO}_{2}$ and $\mathrm{B}_{2} \mathrm{O}_{3}$. In this work, new types of composites consisting of micron size diamonds with borides are investigated with regard to their resistance to high temperatures up to $1000^{\circ} \mathrm{C}$, because it is the most often temperature in the cutting zone.

\section{EXPERIMENTAL}

\section{Materials}

In these studies, one group of PCD materials was prepared using the mixture containing $90 \mathrm{wt} \%$ of Micron+MDA M36 diamond powder of size 3-6 $\mu \mathrm{m}$ (produced by the Element 6,) and $10 \mathrm{wt} \%$ of $\mathrm{TiB}_{2}$ (American Elements, $<100 \mathrm{~nm}$ ), the second batch of a PCD material was prepared using the mixture of the same diamond powder with $5 \mathrm{wt} \%$ of $\mathrm{TiB}_{2}$ and $2 \mathrm{wt} \%$ of Co (ABCR, 0.5-1.5 $\mu \mathrm{m}$ ). The mixtures were pressed at $90 \mathrm{MPa}$ into cylindrical shapes $15 \mathrm{~mm}$ in diameter. Before sintering, the powders were treated at $600^{\circ} \mathrm{C}$ and $0.8 \mathrm{~Pa}$ for $30 \mathrm{~min}$ and closed in a niobium foil container. Next, the materials were sintered using a Bridgman-type high-pressure apparatus at $8.0 \pm 0.2 \mathrm{GPa}$ and $2000 \pm 50{ }^{\circ} \mathrm{C}$. The samples were heated in an internal graphite heater with an inside diameter of $15 \mathrm{~mm}$. Some of these materials properties are presented in the table. The microstructure investigations were performed using the scanning (Jeol JSM-6460LV) microscope. The samples for microanalysis were prepared by lapping on a cast iron plate with diamond paste.

\section{Selected properties of diamond composite}

\begin{tabular}{ccc|cc}
\hline Composition, wt \% & Density*, g/cm & Hardness**, GPa & Young's modulus, GPa \\
\hline 90 diamond + $10 \mathrm{TiB}_{2}[9]$ & 3.38 & $45.4 \pm 2.4$ & $552 \pm 14$ \\
93 diamond $+5 \mathrm{TiB}_{2}+2 \mathrm{Co}$ & 4.04 & $66.6 \pm 2.9$ & $834 \pm 23$ \\
\hline
\end{tabular}

*Average measurement for three samples.

** Average of five hardness measurements, $\alpha=0.05$. 
For the comparison purpose the tests of commercial material with cobalt bonding phase containing $88 \mathrm{wt} \%$ of diamond, $10 \mathrm{wt} \%$ Co and $2 \mathrm{wt} \% \mathrm{WC}$ (from milling process) are also presented.

The density was measured using the hydrostatic method. The hardness was determined by the Vickers method under a load of $9.81 \mathrm{~N}$, using a Future Tech FLC-50VX Vickers hardness tester. For each sample 5 indentations were realized. Young's moduli of composites were measured based on the velocity of the ultrasonic waves transition through the sample using the ultrasonic flaw detector Panametrics Epoch III. The calculations were carried out according to the equation:

$$
E=\rho C_{T}^{2} \frac{3 C_{L}^{2}-4 C_{T}^{2}}{C_{L}^{2}-C_{T}^{2}}
$$

where $E$ - Young's modulus; $\rho$ - density of the material; $C_{L}$ - velocity of the longitudinal wave; $C_{T}$ - velocity of the transversal wave.

The velocities of transversal and longitudinal waves were determined as the ratio of the sample thickness and the relevant transition time. Considering that the error in the thickness measurements was $\pm 0.01 \mathrm{~mm}$ and in the time-of-flight measurements $\pm 1 \mathrm{~ns}$, the resulting error in the ultrasonic velocity was about $1 \%$. Consequently, the accuracy of Young's modulus calculated from equation (1) could be estimated at $2 \%$.

Phase compositions of the sintered bodies were identified by X-ray diffraction analysis, based on the ICDD database. XRD measurements were taken with an X’Pert Pro system (Panalytical) with monochromatic $\mathrm{CuK \alpha _{1 }}$ radiation.

\section{Thermal analysis of starting powders and diamond composites}

Simultaneous thermogravimetric (TG) and differential thermal analysis (DTA) measurements with a NETZSCH STA 449 F3 analyzer were carried out for diamond MDA 36 (produced by Element Six) micropowders, sintered materials, and for the commercial material with $10 \mathrm{wt} \% \mathrm{Co}$ and $2 \mathrm{wt} \% \mathrm{WC}$. The $\mathrm{Al}_{2} \mathrm{O}_{3}$ crucible was used, heating rate was $10^{\circ} \mathrm{C} / \mathrm{min}$ and maximum temperature was $1000^{\circ} \mathrm{C}$. The measurements were carried out in argon (gas moisture $3 \mathrm{ppm} / \mathrm{mol}$, presence of oxygen $2.00 \mathrm{ppm} / \mathrm{mol}$, and hydrocarbons $0.5 \mathrm{ppm} / \mathrm{mol}$ ) and in air. The analyses were carried out using the Netzsch Proteus analysis program. The phase composition of diamond composites was studied after differential and thermogravimetric analyses.

\section{Raman scattering characterization of carbon bonding in diamond composites during heating}

All in situ Raman experiments detailed in Fig. 1 were performed in the CCR1000 reaction cell from Linkam, placed in Jobinn-Yvonne's Labram HR confocal micro-Raman unit based on Czerny-Turner's monochromator. For experimental purposes, micro-Raman was working with the $325 \mathrm{~nm}$ laser line as an excitation source, 2400 (grooves $/ \mathrm{mm}$ ) grating, long distance optical objective (50×) and Synapse CCD as a detector (1024). The samples of diamond powder and sintered composites with diameter smaller than $0.5 \mathrm{~cm}$ were mounted on a ceramic wool filter placed inside the ceramic heating element in CCR1000 cell. In the course of the experiment the samples were purged with a stream of gas (helium or air) with a flow rate of $20 \mathrm{ml} / \mathrm{min}$. Laser power output was set to $5 \mathrm{~mW}$. The reaction cell parameters such as: temperature, rate of heating and cooling were controlled with Linksys program, whereas Labram HR was managed by Labspec 5, where the type of grating, laser source, size of confocal hole, time and number of 
spectra acquisition were determined. All Raman spectra were taken with a $1000 \mu \mathrm{m}$ confocal hole, and $10 \mathrm{~s}$ as the acquisition time and 2 as the acquisition number. The procedure of measurements was as follows. At first the spectrum was collected at room temperature. Then, the cell was heated up to $400{ }^{\circ} \mathrm{C}$ with $50{ }^{\circ} \mathrm{C} / \mathrm{min}$ rate and during this period spectra were collected one by one. When the temperature reached $400{ }^{\circ} \mathrm{C}$, Raman measurement was quickly turned off and again turned on for 10 minutes. During these 10 minutes time Raman spectra were collected one by one like during heating. After that time, Raman analysis was tuned off and on again, but only for one measurement. When this single analysis was finished, temperature was raised to $600{ }^{\circ} \mathrm{C}$ with $50^{\circ} \mathrm{C} / \mathrm{min}$ rate and the above procedure was repeated for 600 and $800{ }^{\circ} \mathrm{C}$. After that, reactor cell was cooled to room temperature and the last Raman spectrum was taken. Raman measurement program course is shown in Fig. 1.

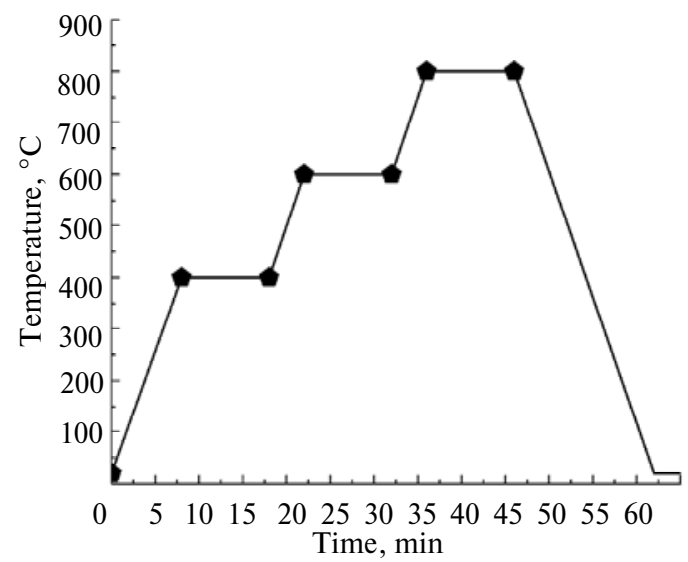

Fig. 1. CCR1000 measurement program parameters for Raman experiments in air and helium: selected measurement points ( $\bullet$ ).

\section{Ball-on-disc tests at elevated temperatures}

The $\mathrm{Al}_{2} \mathrm{O}_{3}$ ceramic ball was used in the ball-on-disc test to measure coefficients of friction dependence on the temperature. The tests for diamond composites in a sliding contact with an $\mathrm{Al}_{2} \mathrm{O}_{3}$ ceramic ball were carried out from room temperature (RT) up to $800^{\circ} \mathrm{C}$, using a CETR UMT-2MT universal mechanical tester (produced at the USA). The size of the disc-shaped samples was $13.5 \times 3.8 \mathrm{~mm}$. The surface of the disc was flat and parallel to within $0.02 \mathrm{~mm}$ and the roughness of the test surface was not higher than $0.1 \mu \mathrm{m}$ Ra. Before the tests, both the ball and disc samples were washed in ethyl alcohol and dried. The following test conditions were established: ball diameter: $3.175 \mathrm{~mm}$, applied load: $4 \mathrm{~N}$, sliding speed: $0.1 \mathrm{~m} / \mathrm{s}$, diameter of the sliding circle: $4 \mathrm{~mm}$, sliding distance: $200 \mathrm{~m}$, duration of the test: $2000 \mathrm{~s}$, temperatures: RT, 200, 400, 600, 700 and $800{ }^{\circ} \mathrm{C}$. The tests were carried out without a lubricant. The friction coefficient was calculated from equation:

$$
\mu=\frac{F_{t}}{F_{n}},
$$

where $F_{t}$ - measured friction force; $F_{n}$ - applied normal force.

After the tests, the phase compositions of the samples were analyzed. 


\section{RESULTS AND DISCUSSION}

Some of the selected properties of diamond composites with $10 \mathrm{wt} \%$ ceramic phase $\mathrm{TiB}_{2}$ are given in the table. Porosity for this material is about $0.83 \%$, values of hardness and Young's modulus were not so high. Szutkowska et al. [9] characterized the phase composition and microstructure of this material. The material consists of $5.9 \mathrm{wt} \%$ of $\mathrm{TiB}_{2}, 1.3 \mathrm{wt} \%$ of $\mathrm{TiC}$, and $1.8 \mathrm{wt} \%$ of graphite. The diamond- $-\mathrm{TiB}_{2}$ composite sintering proceeds in the solid state and the diamond particles surface appears to be in an unfavourable stress state. Graphite appears on the diamond crystallites surfaces, which are not in contact with another diamond surface (in voids) because of the non-isostatic stress distribution on diamond particle surfaces during the high-pressure sintering, and thermodynamical conditions are favourable for graphite presence. For $\mathrm{TiB}_{2}$ the mass transport for densification is limited. In addition, a thin oxygen-rich layer existing on the surface of $\mathrm{TiB}_{2}$ powder hinders the sintering [10]. Because of these difficulties and in effect of the presence of pores in the diamond- $\mathrm{TiB}_{2}$ composite, the $\mathrm{TiB}_{2}$ amount was decreased, and $2 \mathrm{wt} \%$ of Co was added to the mixture.

X-ray diffraction pattern of diamond- $10 \mathrm{wt} \% \mathrm{TiB}_{2}$ composites after the HPHT sintering (as a received sample) and their composition after heating up to $800^{\circ} \mathrm{C}$, in air, during $375 \mathrm{~min}$ (after the wear test) is presented in [11]. After heating up to $800{ }^{\circ} \mathrm{C}$ during wear test graphite and rutile appear in the material.

X-ray diffraction pattern of a diamond- $\mathrm{TiB}_{2}-\mathrm{Co}$ composite after the HP-HT sintering (as a received sample) and its composition after heating to $800^{\circ} \mathrm{C}$, in air, during 375 min (after the wear test) is presented in Fig. 2.

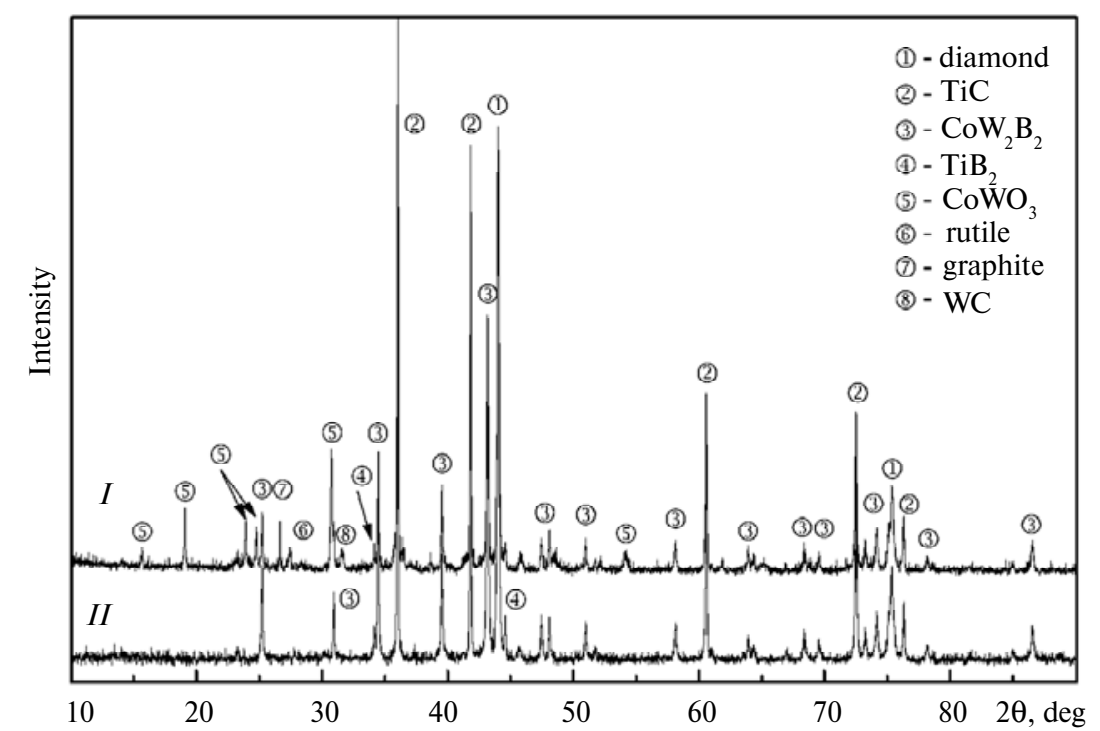

Fig. 2. X-ray diffraction pattern of diamond composites with $\mathrm{TiB}_{2} /$ Co bonding phase after the HP-HT sintering and after wear test at temperatures up to $800{ }^{\circ} \mathrm{C}$ in air: $I$ - after wear test; $I I$ - as received.

For sintered compacts of diamond powder with $5 \mathrm{wt} \%$ of $\mathrm{TiB}_{2}$ and $2 \mathrm{wt} \%$ of Co, the X-ray diffraction indicates $88.1 \mathrm{wt} \%$ diamond, $7.3 \mathrm{wt} \% \mathrm{TiC}, 0.7 \mathrm{wt} \%$ $\mathrm{TiB}_{2}, 3.9 \mathrm{wt} \% \mathrm{~W}_{2} \mathrm{CoB}_{2}$ (tungsten is the additive from the milling process). $\mathrm{TiB}_{2}$ participates in the $\mathrm{W}_{2} \mathrm{CoB}_{2}$ formation as a donor of boron, which diffuses into samples and interacts with cobalt and tungsten carbide. $\mathrm{W}_{2} \mathrm{CoB}_{2}$ microhardness 
$H \mu 50$ is above $45.4 \mathrm{GPa}$ and it is a wear-resistant material [12]. Co addition has significant influence on the graphite content; it is not detectable in compacts and gives good mechanical properties of the material presented in the table.

Microstructures of diamond- $\mathrm{TiB}_{2}$ and diamond-TiB $2-\mathrm{Co}$ composites are shown in Fig. 3.

The microstructure of the diamond- $\mathrm{TiB}_{2}-\mathrm{Co}$ composite and $\mathrm{Ti}$, Co, C elements distribution is given in Fig. 4.

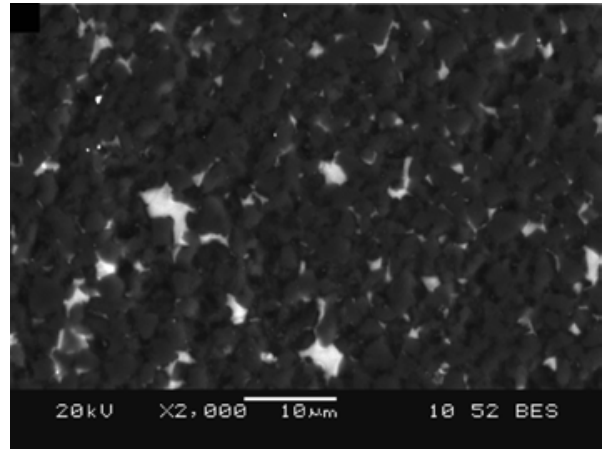

$a$

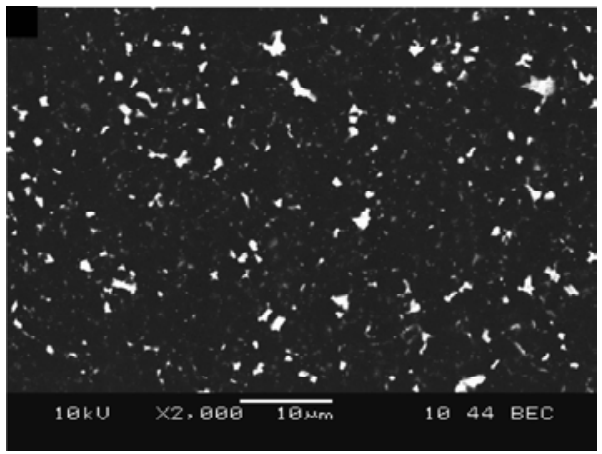

$b$

Fig. 3. BEC microstructures of the samples of the diamond composite with $10 \mathrm{wt} \% \mathrm{TiB}_{2}(a)$; the diamond composite with 5 wt $\% \mathrm{TiB}_{2}$ and 2 wt \% Co $(b)$ taken in back-scattered electron at $2000 \times$ magnification.

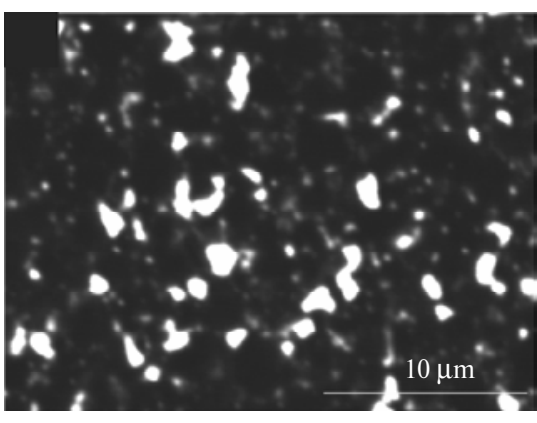

$a$

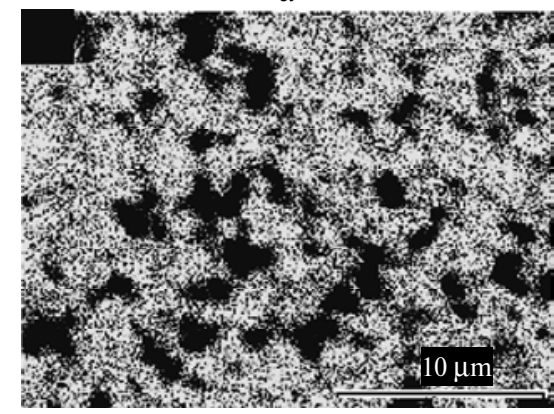

C

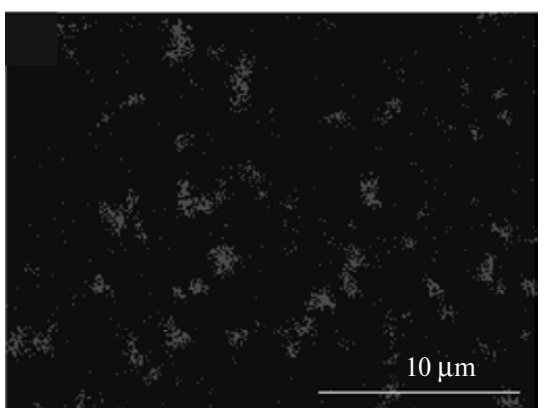

b

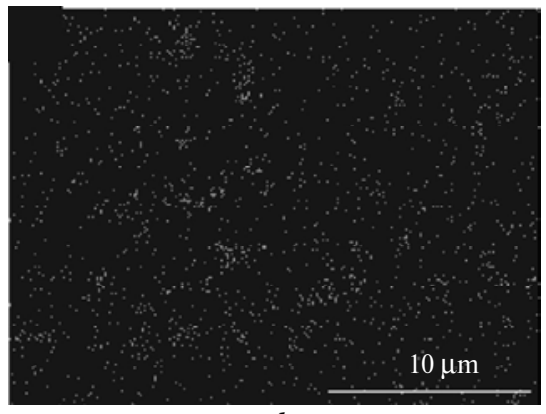

$d$

Fig. 4. SEM microstructure of the samples with $5 \mathrm{wt} \% \mathrm{TiB}_{2}$ and 2 wt $\% \mathrm{Co}$, at magnification $5000 \times(a)$; EDS analysis of diamond compact mapping of Ti dispersion (b); C dispersion (c); Co dispersion $(d)$.

Thermal properties of diamond composites depend strongly on the type of diamond micropowders, their method of synthesis, used catalysts and the type of the bonding phase. The thermoanalytical studies of diamond and $\mathrm{TiB}_{2}$ powders with 
the DTA-TG methods are presented in Fig. 5. The analysis was carried out in air and argon.

For the natural diamond the TG and DTA curves confirmed two types of chemical reactions, first at temperatures above $960{ }^{\circ} \mathrm{C}$ and second above $1060{ }^{\circ} \mathrm{C}$. In the low-temperature oxidation stage the $2 \mathrm{C}+\mathrm{O}_{2}=\mathrm{CO}$ reaction occurs, during the high-temperature stage desorption and $\mathrm{C}+\mathrm{O}_{2}=\mathrm{CO}_{2}$ reaction takes place [13]. The beginning of the DTA peak for the MDA synthetic diamond studies carried out in argon is at $490{ }^{\circ} \mathrm{C}$ and the maximal value of the peak is at about $600{ }^{\circ} \mathrm{C}$. The beginning of the DTA peak for the studies carried out in air is at $480^{\circ} \mathrm{C}$ and the maximal value of the peak is at $570^{\circ} \mathrm{C}$ (see Fig. 5, a). It was noted a sharp exothermic effect in the DTA curve during the heating, which is assumed to result from oxidation and evaporation (which is due to the trace amounts of oxygen in the apparatus and argon as well as the release of moisture). Gaseous products CO and $\mathrm{CO}_{2}$ are the results of diamond oxidation.
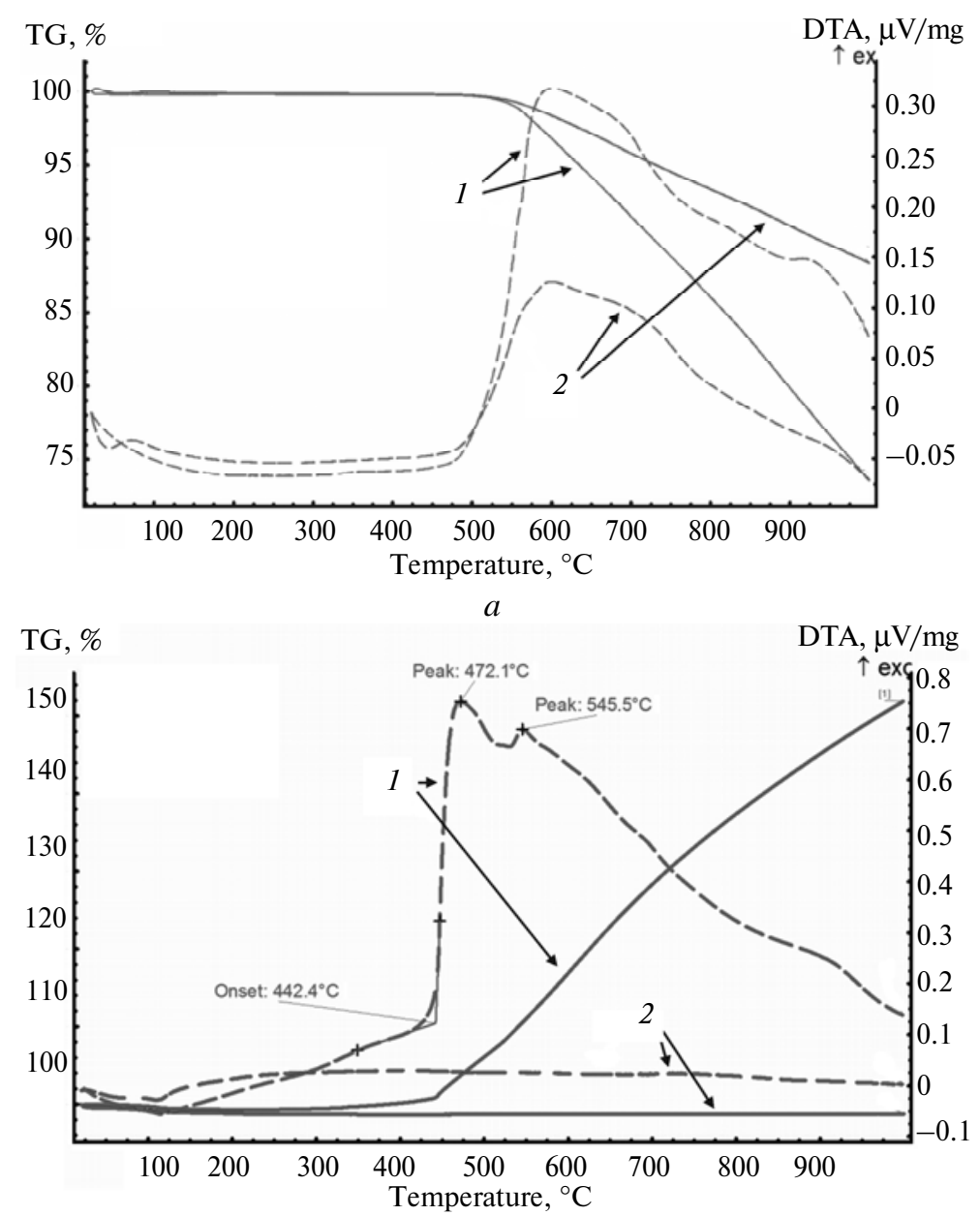

$b$

Fig. 5. DTA-TG curves for: MDA 36 diamond micropowder (produced by the Element 6) (a), $\mathrm{TiB}_{2}$ powder (b); diamond 3-6 $\mu \mathrm{m}$ and $\mathrm{TiB}_{2}$ in air (1) and argon (2) flow, DTA (- - -), TG (-).

The beginning of the DTA peak of the $\mathrm{TiB}_{2}$ tests carried out in air is at $442^{\circ} \mathrm{C}$ and the maximal value of the peak is at about $472{ }^{\circ} \mathrm{C}$. $\mathrm{TiB}_{2}$ at argon is very stable (see Fig. $5, b$ ). $\mathrm{TiB}_{2}$ has the tendency to the surface oxidation. Koh et al. [14] 
reported the oxidation of hot-pressed $\mathrm{TiB}_{2}$. This process showed two distinct oxidation behaviours depending on the exposure temperature. At the temperatures below $1000{ }^{\circ} \mathrm{C}$, parabolic weight gain was observed as a result of the formation of $\mathrm{TiO}_{2}$ and $\mathrm{B}_{2} \mathrm{O}_{3}$ on the surface. At the temperatures above $1000^{\circ} \mathrm{C}$, crystalline $\mathrm{TiO}_{2}$ formed along with gaseous $\mathrm{B}_{2} \mathrm{O}_{3}$ due to the oxidation [14]. The DTA results for $\mathrm{TiB}_{2}$ nonopowders heated in air, showed a sharp exothermic effect at $472^{\circ} \mathrm{C}$. $\mathrm{TiB}_{2}$ heated in argon did not have any significant reactions or phase changes from room temperature up to $1000^{\circ} \mathrm{C}$.

The thermal analysis results for sintered materials and for the commercial material with $10 \mathrm{wt} \%$ Co and $2 \mathrm{wt} \% \mathrm{WC}$ in argon and in air are shown in Figs. 6, $a, b, c$.

The composites with cobalt (see Figs. 6, $b$ and $c$ ) heated in air, are presenting similar tendency during DTA/TG studies. Figures $6, b$ and $c$ show exotherms with an onset temperature of $923.9^{\circ} \mathrm{C}$, but associated TG results showed a more intensive weight loss for the commercial material without $\mathrm{TiB}_{2}$ participation and a decrease of the composite mass starts at about $797.8^{\circ} \mathrm{C}$, while for a composite with $\mathrm{TiB}_{2}$ and $\mathrm{Co}$ at about $877.2^{\circ} \mathrm{C}$. For a composite with $10 \mathrm{wt} \% \mathrm{TiB}_{2}$, TG results are similar to the composite with $\mathrm{TiB}_{2}$ and Co, but DTA up to $1000^{\circ} \mathrm{C}$ shows two endotherms with onset temperatures of 704.0 and $912.0^{\circ} \mathrm{C}$.
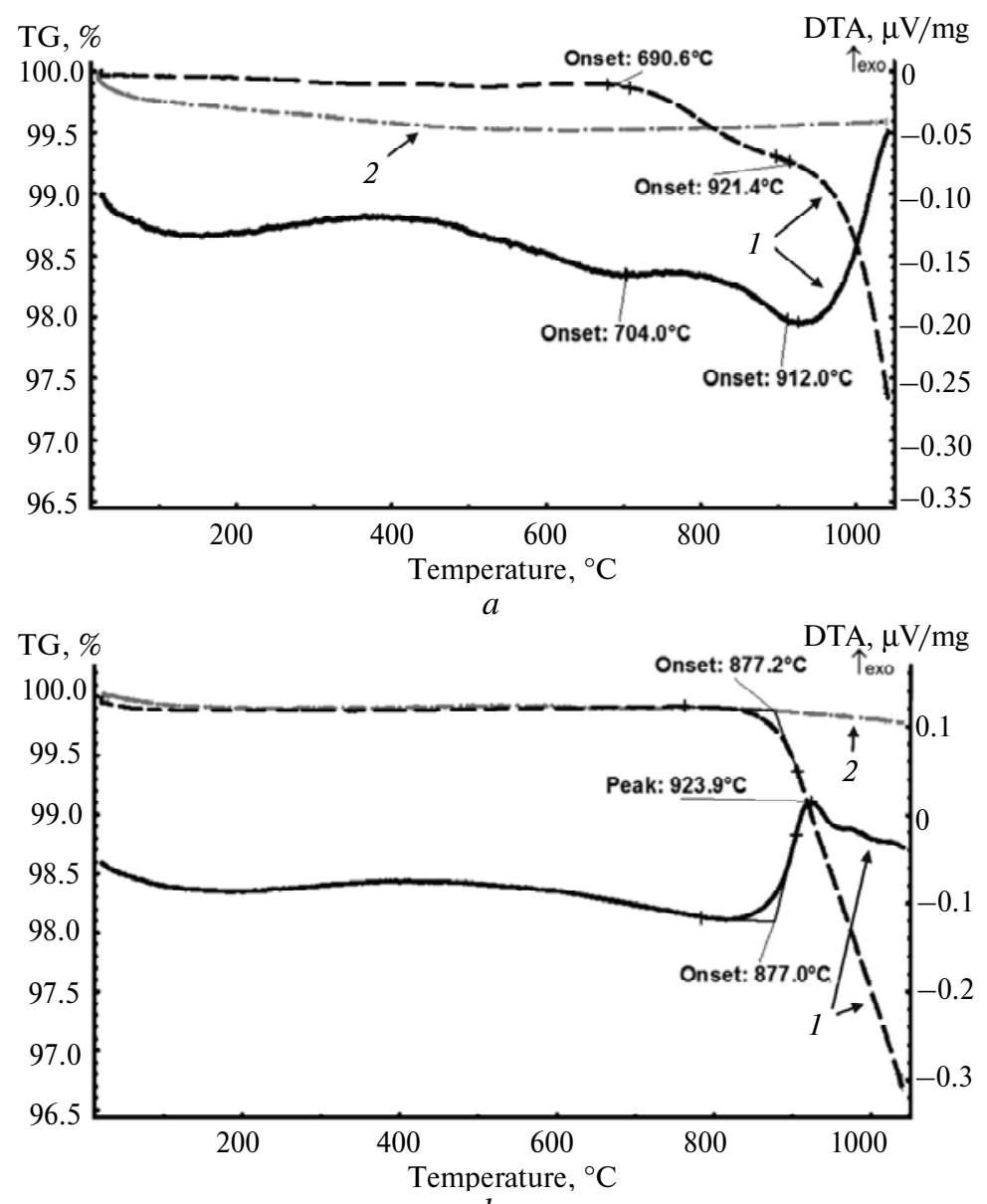

$b$

Fig. 6. DTA-TG curves for diamond composites: $90 \mathrm{wt} \%$ diamond-10 wt $\% \mathrm{TiB}_{2}(a)$, $93 \mathrm{wt} \%$ diamond $-5 \mathrm{wt} \% \mathrm{TiB}_{2}$ and $2 \mathrm{wt} \% \mathrm{Co}(b)$; $88 \mathrm{wt} \%$ diamond $-10 \mathrm{wt} \% \mathrm{Co}+2 \mathrm{wt} \% \mathrm{WC}$ (commercial) (c); diamond- $\mathrm{TiB}_{2}$ in air (1) and argon (2) flow, DTA (-), TG (- - -). 


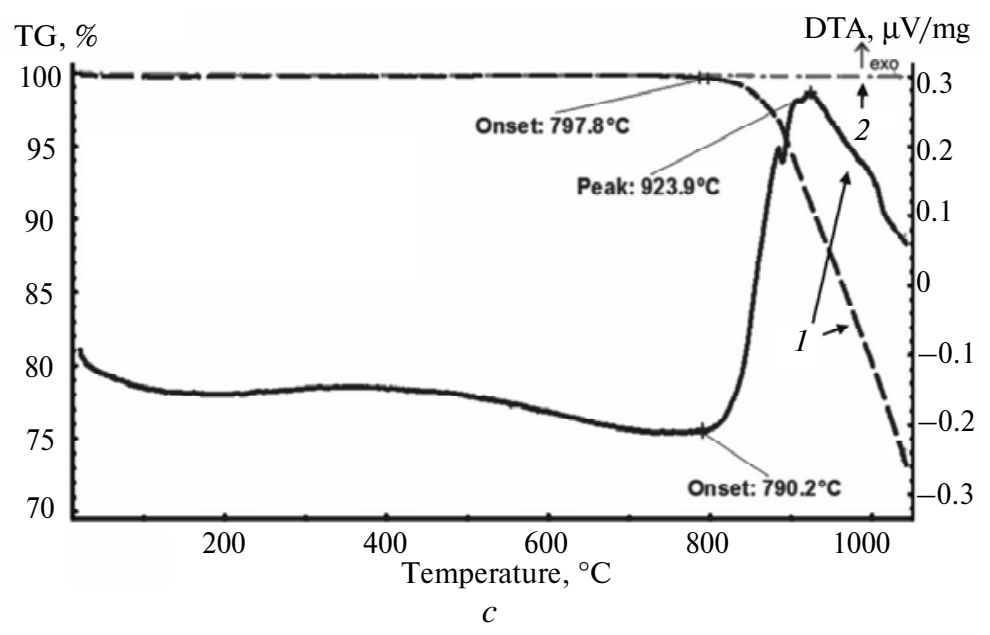

Fig. 6. (Contd.)

In Raman spectroscopy the sharp features at 1332 and $1580 \mathrm{~cm}^{-1}$ are the firstorder zone centre modes of diamond and graphite, respectively. These frequencies are indicative of different bond strengths of the diamond and graphite bonding. It should be noted that the $1332 \mathrm{~cm}^{-1}$ mode in diamond is essentially the highest energy vibrational mode of the structure, while for graphite, a second-order feature is observed at $3240 \mathrm{~cm}^{-1}$, which is due to slightly higher phonons energy than the mode at $1580 \mathrm{~cm}^{-1}$. In these studies both modes 1332 and $1580 \mathrm{~cm}^{-1}$ for diamond and graphite were observed [15]. The solvent phase between the diamond grains consists of cobalt, which helps to promote the direct bonding of diamond grains during sintering. For ceramic bonding phases the direct diamond-diamond bonding becomes very difficult. Each data point corresponds to the measured zone centre phonon frequency for diamond and graphite (Figs. 7, 8). The studies were carried out in air and in helium. In Figs. 7, $a$ and $b$, Raman spectra in heating up to $800{ }^{\circ} \mathrm{C}$ of diamond- $\mathrm{TiB}_{2}$ and diamond- $-\mathrm{TiB}_{2}-\mathrm{Co}$ composites in air are presented.

Diamond with the $\mathrm{TiB}_{2}$ bonding phase is a material more resistant to the oxidation (see Fig. 7, a). Raman spectrometry confirms that graphite is present in the phase composition of the diamond with $\mathrm{TiB}_{2}$ composite, up to $800^{\circ} \mathrm{C}$. For the diamond- $\mathrm{TiB}_{2}-\mathrm{Co}$ composite at room temperature Raman spectroscopy detected minor amounts of graphite. At $400{ }^{\circ} \mathrm{C}$ the graphite peak is stronger and it disappears at $600{ }^{\circ} \mathrm{C}$ because of the intensive oxidation

At studies in helium (Figs. 8, $a, b$ ) both diamond composites are stable up to about $800{ }^{\circ} \mathrm{C}$, with very little graphite intensity changing. After heating at $400{ }^{\circ} \mathrm{C}$ for the composite with $\mathrm{TiB}_{2}$-Co bonding phase the graphite peak intensity is decreasing, probably because of a low amount of oxygen in helium and oxidization process. Graphite (which is cumulated on the diamond particles surfaces) is the main participant during the diamond oxidation process.

The graphite participation for the sample after the wear test is not visible for diamond with $\mathrm{TiB}_{2}$ and the minor amount $0.3 \mathrm{wt} \%$ is detected for diamond composite with $\mathrm{TiB}_{2}$ and $\mathrm{Co}$. CO gas emission breaches the integrity of the composite microstructure. Additionally, a large quantity of rutile appears in material content, reducing hardness of composite with $\mathrm{TiB}_{2}$ bonding phase.

A low coefficient of friction is one of the most important characteristics for the cutting materials since its value affects the smoothness and surface quality of the workpiece. The coefficients of friction for diamond composites in a sliding contact 
with an $\mathrm{Al}_{2} \mathrm{O}_{3}$ ceramic ball were determined at temperatures from RT up to $800{ }^{\circ} \mathrm{C}$ (close to the temperature in the cutting zone) in ball-on-disc tests. The of coefficient of friction values in dependence on the temperature for the diamond composite with $10 \mathrm{wt} \%$ of $\mathrm{TiB}_{2}$, diamond with $5 \mathrm{wt} \%$ of $\mathrm{TiB}_{2}$ and $2 \mathrm{wt} \%$ of $\mathrm{Co}$ and for the commercial materials with the Co bonding phase are presented in Fig. 9.
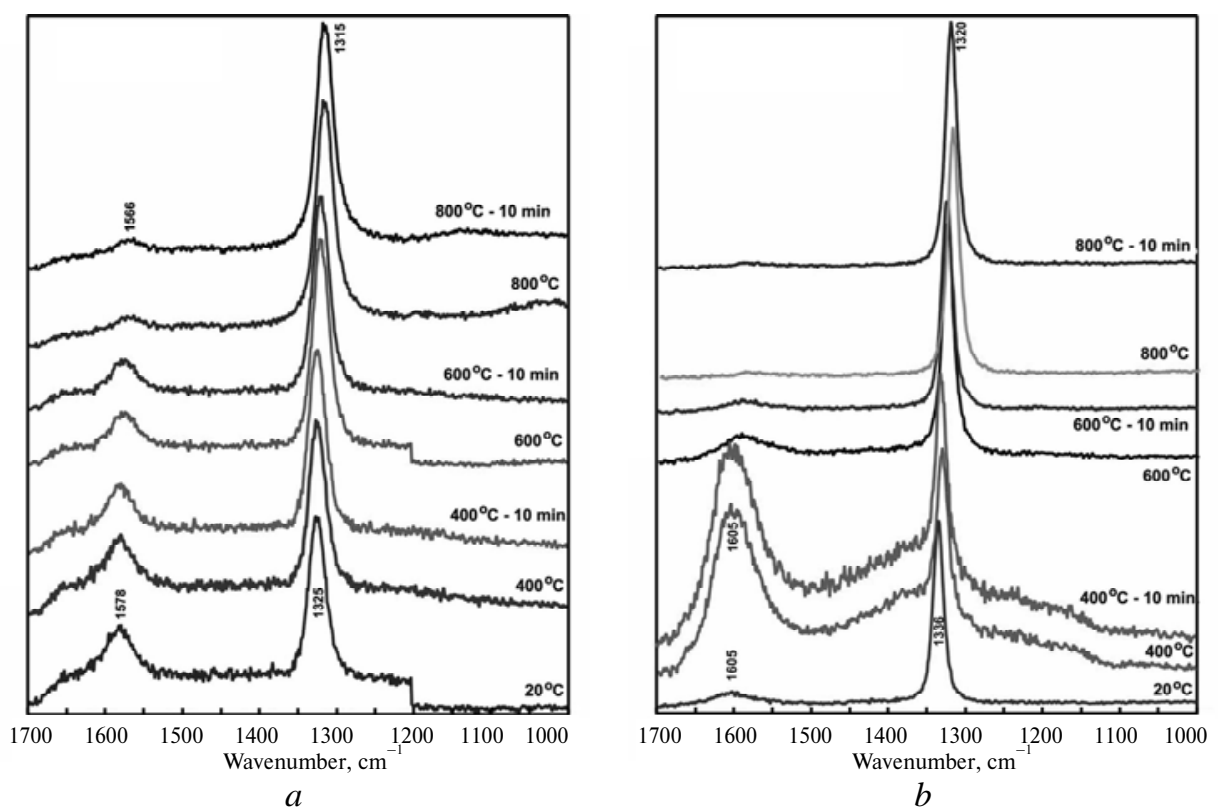

Fig. 7. Raman spectra of diamond composites, observed for the first-order zone centre modes of diamond and graphite during heating up to $800{ }^{\circ} \mathrm{C}$ in air, for diamond with $10 \mathrm{wt} \% \mathrm{TiB}_{2}(a)$ and during for diamond composite with the $\mathrm{TiB}_{2}-\mathrm{Co}$ bonding phase $(b)$.

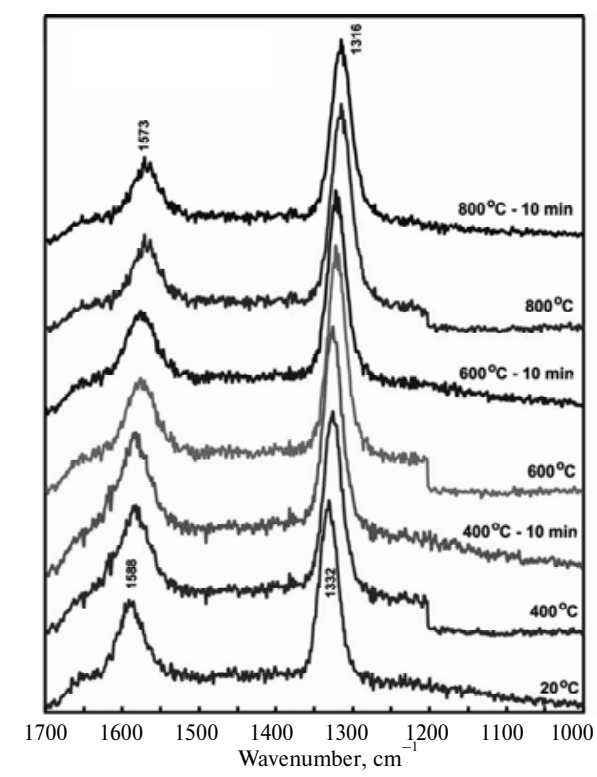

$a$

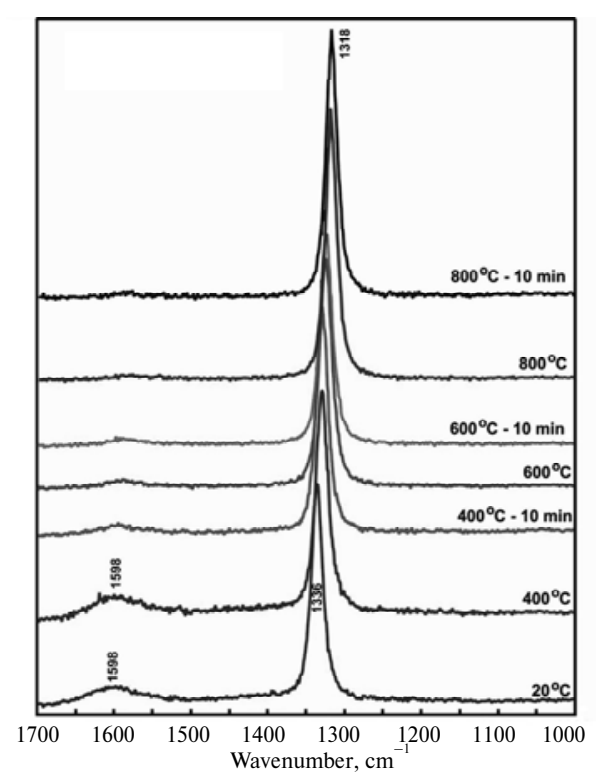

$b$

Fig. 8. Raman spectra of diamond composites with the $\mathrm{TiB}_{2}$ bonding phase $(a)$ and $\mathrm{TiB}_{2}-\mathrm{Co}$ bonding phase $(b)$, observed for the first-order zone centre modes of diamond and graphite during the heating up to $800^{\circ} \mathrm{C}$ in helium. 
The results of the coefficient of friction measurements for diamond composites shown in Fig. 9 confirm that the coefficients strongly depend on the temperature. For all composites, the friction coefficients are lower at $200^{\circ} \mathrm{C}$ than at RT. For diamond with $\mathrm{TiB}_{2}$ the friction coefficient at $400^{\circ} \mathrm{C}$ is similar to the friction coefficient at RT. The diamond composite with $\mathrm{TiB}_{2}$ is the most thermally stable material. Its friction coefficient at $400^{\circ} \mathrm{C}$ is about 0.16 . For the commercial PCD material and diamond composite with $\mathrm{TiB}_{2}$ and $\mathrm{Co}$, the friction coefficients are increasing from 200 and at $400{ }^{\circ} \mathrm{C}$ friction coefficients are about 0.3 and 0.65 , respectively. The coefficients of friction for composite with $\mathrm{TiB}_{2}$ at room temperature are lower than for the commercial material and composite with $\mathrm{TiB}_{2}$ and Co. The coefficients of friction changes are the result of the phase transitions.

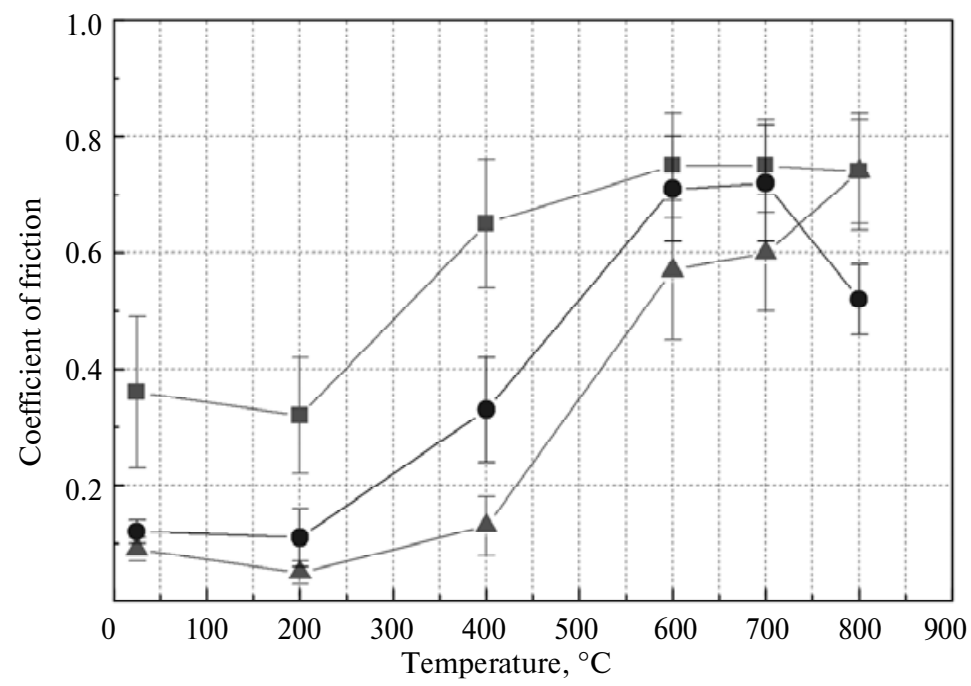

Fig. 9. Friction coefficients of diamond composites as a function of heat treatment temperature (air atmosphere) during sliding against $\mathrm{Al}_{2} \mathrm{O}_{3}$ ball at 20, 200, 400, 600, 700 and $800{ }^{\circ} \mathrm{C}$ : 90 wt \% diamond +10 wt \% $\mathrm{TiB}_{2}$ nano $(\boldsymbol{\Delta}), 93 \mathrm{wt} \%$ diamond $+5 \mathrm{wt} \% \mathrm{TiB}_{2}$ nano $+2 \mathrm{wt} \% \mathrm{Co}(\mathbf{\square}), 88$ wt $\%$ diamond +10 wt $\%$ Co +2 wt \% WC (commercial) (

The diamond with 10 wt $\%$ of $\mathrm{TiB}_{2}$ composite after the high-pressure process consists of diamond, $5.9 \mathrm{wt} \% \mathrm{TiB}_{2}, 1.3 \mathrm{wt} \% \mathrm{TiC}$, and $1.8 \mathrm{wt} \%$ of graphite [11]. After the wear test in the material $6 \mathrm{wt} \%$ of rutile appears, the rest of bonding phase consists of $\mathrm{TiB}_{2}$; graphite is not detectable in the material because of the oxidation process and gaseous $\mathrm{CO}, \mathrm{CO}_{2}$ forming. The composition of diamond composite with $\mathrm{TiB}_{2}$ and Co after the wear test up to $800{ }^{\circ} \mathrm{C}$ is multiphase. This composite contains $\mathrm{W}_{2} \mathrm{CoB}_{2}$, the amounts of $\mathrm{TiB}_{2}$ and $\mathrm{TiC}$ are almost the same. There is a low amount of rutile $0.8 \mathrm{wt} \%$, graphite about $0.3 \mathrm{wt} \%, 0.1 \mathrm{wt} \% \mathrm{Co}$, and $1.3 \mathrm{wt} \%$ of $\mathrm{CoWO}_{4}$, but the amount of diamond is about $4 \mathrm{wt} \%$ lower (84 wt \%) than for the material before the wear test (see Fig. 3). In the diamond composite with $\mathrm{TiB}_{2}$ titanium and graphite oxidation occurs while rutile is forming. For the diamond composite with $\mathrm{TiB}_{2}$ and Co, cobalt and diamond mainly take part in the oxidation. Rutile and especially $\mathrm{W}_{2} \mathrm{CoB}_{2}$ participation in the bonding phase content decreases the friction coefficients of diamond composites.

Hardness of materials depends on the heat treatment temperature (after wear tests up to $800^{\circ} \mathrm{C}$ ), and it was compared to the commercial diamond-cobalt PCD. The results are presented in Fig. 10. 


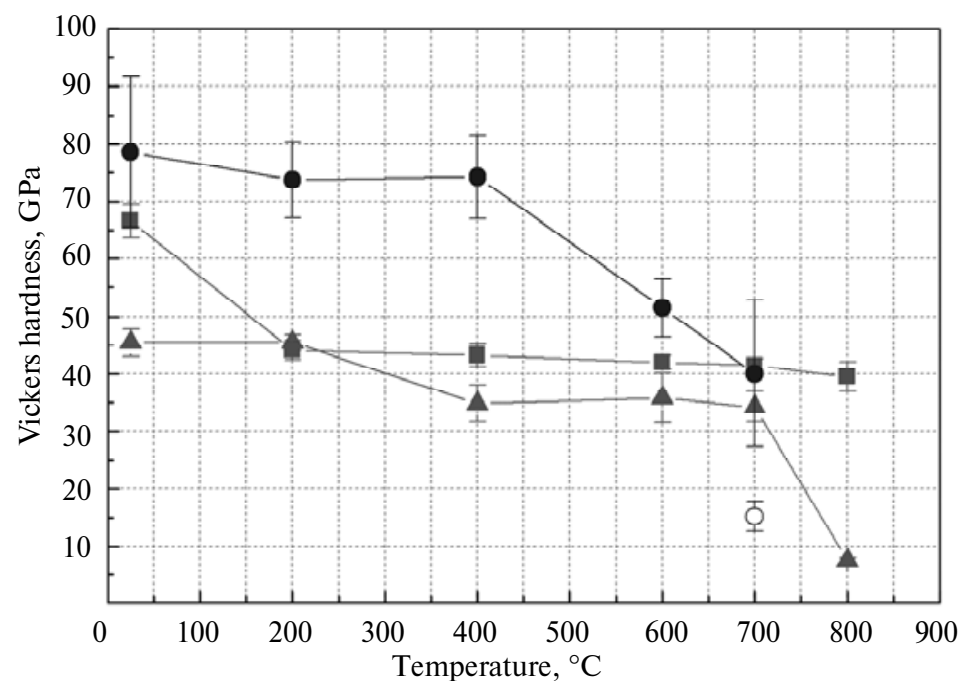

Fig. 10. Vickers hardness of diamond composites as a function of the heat treatment temperature (air atmosphere) after the wear tests: $90 \mathrm{wt} \%$ diamond $+10 \mathrm{wt} \% \mathrm{TiB}_{2}$ nano $(\mathbf{\Delta})$, $93 \mathrm{wt} \%$ diamond +5 wt $\% \mathrm{TiB}_{2}$ nano $+2 \mathrm{wt} \%$ Co (ם), 88 wt \% diamond $+10 \mathrm{wt} \%$ Co $+2 \mathrm{wt} \% \mathrm{WC}$ (commercial) (

The most resistant to the hardness changes at elevated temperatures is diamond with $\mathrm{TiB}_{2}$ and $\mathrm{Co}$. This material maintains high hardness value up to $800{ }^{\circ} \mathrm{C}$ (see Fig. 10). For diamond with $\mathrm{TiB}_{2}$ above $700{ }^{\circ} \mathrm{C}$ the hardness decreases because of the oxidation and formation of rutile. For commercial PCD material with the cobalt bonding phase, above $400{ }^{\circ} \mathrm{C}$ there is a rapid decrease of hardness and no measurable hardness at $800{ }^{\circ} \mathrm{C}$ (see Fig. 10). The reason of hardness decrease for all investigated materials is explained by the oxidation process.

\section{CONCLUSIONS}

It has been found that because of the solid state HP-HT sintering of the diamond- $\mathrm{TiB}_{2}$ composite, the material is characterized by a low amount of graphite participation, about $1.8 \mathrm{wt} \%$. Mechanical properties of this material (especially hardness) are lower than for commercial PCD ( $\left.H_{V 1} 45.4 \mathrm{GPa}\right)$ but high thermal resistance of the diamond with $\mathrm{TiB}_{2}$ has been confirmed by the DTA/TG studies and Raman spectrometry at higher temperatures. This composite is characterized by a low value of coefficient of friction up to $700^{\circ} \mathrm{C}$, which is advantageous for the applications for cutting tools.

Diamond PCDs with the $\mathrm{TiB}_{2}$ bonding phase have a very limited change in mass at high temperatures in comparison to the commercial materials with Co bonding phase, they could be used at about 70 degrees higher temperatures. The $\mathrm{TiB}_{2}$ ability to oxidize the surface, is beneficial to reduction of the oxidation that is present in the commercial PCD with cobalt. The TG results showed a more intensive weight loss for the commercial material with the cobalt bonding phase (without $\mathrm{TiB}_{2}$ participation) and the decrease of the composite mass starts at lower temperatures (about $797.8^{\circ} \mathrm{C}$ ) than for composite with $\mathrm{TiB}_{2}$ and $\mathrm{Co}$ (about $\left.877.2^{\circ} \mathrm{C}\right)$.

It has been shown that the addition of cobalt to the diamond with $\mathrm{TiB}_{2}$ improved hardness and Young's modulus of the PCD material because of the porosity reduction. The material contains tungsten ( $\mathrm{W}$ is the additive from the milling process). The bonding phase contains among others, $\mathrm{W}_{2} \mathrm{CoB}_{2}$. This 
compound is thermally stable and very hard but has main influence on a decrease of the coefficient of friction. Diamond with $\mathrm{TiB}_{2}$ and Co is resistant to the hardness changes at elevated temperatures.

The XRD measurements were performed at the Faculty of Materials Science and Ceramics of the AGH University of Science and Technology. We are grateful to Prof. Miroslaw Bucko for these studies.

This work was supported by the 2007-2013 Innovative Economy Programme under the National Strategic Reference Framework EU, priority axis 1, section 1.1.3, project No UDA-POIG.01.03.01-12-024/08-00, 26 March 2009 and Applied Research Programme cofunded by The National Centre of Research and Development project No PBS1/B6/13/2013.

Досліджено полікристалічні алмазні композити - одну групу матеріалів було приготовано з використанням алмазного порошку $і 10 \%$ (за масою) ТіВ 2 , а другу - 3 алмазного порошку, 5 \% (за масою) $\mathrm{TiB}_{2}$ i 2 \% (за масою) Со. Матеріали було спечено в

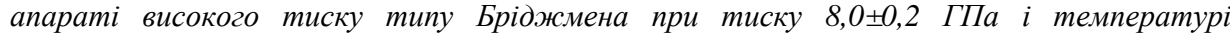
$2000 \pm 50{ }^{\circ} \mathrm{C}$. Термогравіметричні вимірювання та диференційний термічний аналіз було проведено для алмазних мікропорошків, зв'язуючої фази ТіВ ${ }_{2}$ і спечених композітов. Визначено коефіцієнти тертя для алмазних композитів при ковзному контакті з кулькою 3 кераміки $\mathrm{Al}_{2} \mathrm{O}_{3}$ при температурі від кімнатної до $800{ }^{\circ} \mathrm{C}$. Фазові склади матеріалів проаналізовано для вихідних зразків $i$ після їх випробування на знос при температурі $800{ }^{\circ} \mathrm{C}$. Представлено спектри комбінаційного розсіювання алмазних композитів зі зв'язуючими фазами боридів, щуо спостерігаються в ичентрі зони першого порядку алмазу $i$ графіту в прочесі нагрівання до $800{ }^{\circ} \mathrm{C}$ на повітрі. Порівнювали термічні властивості отриманих полікристалічних алмазних композитів $і$ промислового композита алмазкобальт. Було виявлено, щуо алмаз з ТіВ 2 і Со є найбільи стійким до змін твердості при підвищених температурах $i$ зберігає високу твердість до $800{ }^{\circ} \mathrm{C}$, але має високий коефіиієнт тертя.

Ключові слова: PCD, ТіВ 2 зв'язуюча фаза, термостабільність, твердість, коефіиієнт тертя.

Исследованы поликристаллические алмазных композиты - одна группа материалов была приготовлена с использованием алмазного порошка и 10 \% (по массе) $\mathrm{TiB}_{2}$ а вторая - из алмазного порошка, 5 \% (по массе) TiB 2 и 2 \% (nо массе) Со. Материальг были спечены в аппарате высокого давления типа Бриджмена при давлении

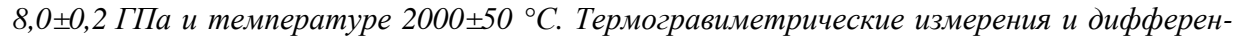
циальный термический анализ были проведень для алмазных микропорошков, связующей фазы тіВ 2 и спеченных композитов. Определень коэффичиенты трения для алмазных композитов при скользящем контакте с шариком из керамики $\mathrm{Al}_{2} \mathrm{O}_{3}$ при температуре от комнатной до $800{ }^{\circ} \mathrm{C}$. Фазовые составы материалов проанализированы для исходных образиов и после их испытания на износ при температуре $800{ }^{\circ} \mathrm{C}$. Представлены спектры комбинационного рассеяния алмазных композитов со связующими фазами боридов, наблюдаемые в иентре зоны первого порядка алмаза и графита в проиессе нагрева до $800{ }^{\circ} \mathrm{C}$ на воздухе. Сравнивали термические свойства полученных поликристаллических алмазных композитов и промымленного поликристаллического композита алмаз-кобальт. Было обнаружено, что алмаз с ТіВ 2 и Со является наиболее устойчивыл к изменениям твердости при повышенных температурах и сохраняет высокую твердость до $800{ }^{\circ} \mathrm{C}$, но имеет высокий коэффициент трения.

Ключевые слова: PCD, связующая фаза ТіВ, термостабильность, твердость, коэффициент трения.

1. Milton S. Metal Cutting Principles / 2nd ed. - New York: Oxford University Press, 2005 $651 \mathrm{p}$.

2. Field J. E. The Properties of Diamond. - Academic Press, 1979. - P. 474-475. 
3. Home J. Y., Jones L. E., Cormack A. N. The oxidation of diamond // Proc. American Carbon Society “Carbon-01" Int. Conf. on Carbon, Lexington, KY, USA, 14-19 July, 2001, paper 6.2. - http://www.acs.omnibooksonline.com/data/papers/2001_6.2.pdf

4. Tankala K., Debroy T., Alam M. Oxidation of diamond films synthesized by hot filament assisted chemical vapor deposition // J. Mater. Res. - 1990. - 5. - P. 2483-2489.

5. Strong H. M., Hanneman R. E. Crystallization of diamond and graphite // J. Phys. Chem. 1967. - 46. - P. 3668.

6. Fedortchouk Y., Canil D. Diamond oxidation at atmospheric pressure: development of surface features and the effect of oxygen fugacity // Eur. J. Mineral. - 2009. - 21. - P. 623-635.

7. Burnsa R. C., Hansena J. O., Spitsa R. A. et al. Growth of high purity large synthetic diamond crystals // Diam. Relat. Mater. - 1999. - 89. - P. 1433-1437.

8. Konstanty J. Powder metallurgy diamond tools - A review of manufacturing routes. Progress in Powder Metallurgy, Part 2 // Mater. Sci. Forum. - 2007. - 534-536. - P. 1121-1124.

9. Szutkowska M., Jaworska L., Rozmus M., Krolicka B. Diamond composite with titanium diboride bonding phase obtained by HP-HT technique // J. Aust. Ceram. Soc. - 2012. - 48. P. 141-143.

10. Baik S., Becher P. F. Effect of oxygen contamination on densification of $\mathrm{TiB}_{2} / / \mathrm{J}$. Am. Ceram. Soc. - 1987. - 70. - P. 527-330.

11. Jaworska L., Szutkowska M., Klimczyk P. et al. Oxidation, graphitization, and thermal resistance of PCD materials with the various bonding phases of up to $800{ }^{\circ} \mathrm{C} / /$ Int. J. Refract. Met. Hard Mater. - 2014. - 45. - P. 109-116.

12. Zachariev Z. New superhard ternary borides in composite materials, metal, ceramic and polymeric composites for various uses / Ed. J. Cuppoletti. - InTech, 2011. - P. 67-72. http://www.intechopen.com/books/metal-ceramic-and-polymeric-composites-for-varioususes/new-superhard-ternary-borides-in-composite-materials

13. Lavrenko V. A., Podchernyaeva I. A., Peikhua K. et al. Effect of cladding diamond powder with a nickel-phosphorus alloy on its high-temperature oxidation // Powder Metall. Met. Ceram. - 1996. - 35, N 1-2. - P. 48-50.

14. Koh Y. H., Lee S. Y., Kim H. E. Oxidation behaviour of titanium boride at elevated temperatures // J. Am. Ceram. Soc. - 2001. - 84. - P. 239-241.

15. Nemanich R. J., Glass J. T., Lucovsky G., Shroder K. E. Raman scattering characterization of carbon bonding in diamond // J. Vac. Sci. Technol. A. - 1988. - 6, N 3. - P. $1783-87$.

Institute of Advanced Manufacturing Technology,

Received 27.10.14

Poland

AGH University of Science and Technology,

Faculty of Materials Science and Ceramics, Poland 